\title{
MANAJEMEN EKSTRAKURIKULER PADA PESERTA DIDIK DI PAUD IT ALHAMDULILLAH YOGYAKARTA
}

\author{
AULIA LAILY RIZQINA \\ Universitas Islam Negeri (UIN) Sunan Kalijaga Yogyakarta \\ Email: Aulialailyrizqina@gmail.com \\ BAYU SURATMAN \\ Universitas Islam Negeri (UIN) Sunan Kalijaga Yogyakarta \\ Email:bayuseladu@gmail.com
}

\begin{abstract}
ABSTRAK
Penelitian ini mendeskripsikan tentang manajemen ekstrakurikuler pada peserta didik di PAUD IT Alhamdulillah Yogyakarta. Tujuan penelitian ini adalah untuk mengetahui bagaimana pelaksanaan manajemen ekstrakurikuler yang dilaksanakan di PAUD IT Alhamdulillah Yogyakarta. Tulisan ini dilakukan dengan metode kualitatif dan pendekatan deskriptif berdasarkan observasi dan wawancara yang dilakukan di PAUD IT Alhamdulillah. Berdasarkan penelitian yang dilakukan bahwa kegiatan ekstrakurikuler di PAUD IT Alhamdulillah dilaksanakan setiap hari. Adapun kegiatan ekstrakurikuler yang dilaksanakan setiap hari, yaitu: drumband, melukis, dan menari. Manajemen ekstrakurikuler dilaksanaka juga dimulai dari tahap perencanaan, pemgorganisasiaan, pelaksanaan, dan evaluasi.
\end{abstract}

Kata Kunci: Manajemen, Ekstrakurikuler, Peserta Didik

\begin{abstract}
This Study describes the extracurricular management of students at PAUD IT Alhamdulillah Yogyakarta. The Purpose of this study was to determine how the implementation of exrtracurricular management carried out at PAUD IT Alhamdulillah Yogyakarta. This paper was conducted with a qualitative method and descriptive approach based on observations and interviews conducted that extracurricular activities in PAUD IT Alhamdulillah are carried out every day. The extracurricular activities carried out every day, namely: drumband, painting, and dancing. Extracurricular management is also carried out starting from the planning, organizing, implementation and evaluation stages.
\end{abstract}

Keywords: Management, Extracurricular, Students

\section{PENDAHULUAN}

Manajemen pendidikan memiliki peran penting dalam mewujudkan sistem pendidikan yang bermutu dan berkelanjutan. Manajemen pendidikan sangat penting karena manajemen pendidikan mengelola sumber daya pendidikan yang meliputi pendidik, tenaga kependidikan, kurikulum, sarana prasarana, anak didik/siswa, 
pembelajaran, sekolah, dan masyarakat.oleh karena itu manajemen pendidikan harus diatur secara profesional. Begitupun manajemen pendidikan PAUD yang memiliki peran sama penting dalam mengelola suatu lembaga pendidikan. PAUD adalah lembaga pendidikan yang diselenggarakan untuk anak usia dini sebelum memasuki pendidikan dasar. Pendidikan Anak Usia Dini wajib diikuti oleh anakanak di seluruh Indonesia. Hal ini sesuai dalam UU Sisdiknas No 20 Tahun 2003 Bab 1, Pasal 1, Ayat 14 yang mengatakan bahwa Pendidikan Anak Usia Dini (PAUD) adalah suatu upaya pembinaan yang ditujukan kepada anak sejak dini sampai usia enam tahun yang dilakukan melalui pemberian rangsangan pendidikan untuk membantu dan perkembangan jasmani dan rohani agar anak memiliki kesiapan dalam memasuki pendidikan lebih lanjut.Manajemen PAUD adalah proses kegiatan perencanaan pengorganisasian pendidikan, memimpin, dan mengendalikan sumber daya manusia guna ketercapaian sasaran organisasi. ${ }^{173}$

Sedangkan aktifitas manajemen dilakukan untuk mempermudah suatu kegiatan. Manajemen PAUD merupakan suatu model atau rancangan yang digunakan oleh suatu lembaga pendidikan untuk mengelola lembaga pendidikan anak usia dini guna menstimulasi perkembangan anak untuk mempersiapkan jenjang pendidikan selanjutnya.Kegiatan PAUD sangatlah beragam. Salah satu kegiatan di PAUD adalah kegiatan ekstrakurikuler. Kegiatan ekstrakurikuler merupakan kegiatan yang dilakukan diluar jam pembelajaran maupun diluar kegiatan aktivitas lembaga PAUD. Hal ini juga dilakukan oleh lembaga PAUD Islam Terpadu Alhamdulillah dalam melakukan manajemen terhadap peserta didik dalam kegiatan ekstrakurikuler. Kegiatan ekstrakurikuler dilakukan diluar jam pembelajaran. Selain itu, kegiatan dilakukan pada jam siang berkisar antara jam 11.00-14.00 WIB. Kegiatan pada ekstrakurikuler bertujuan agar peser didik dapat mengembangkan minat dan bakat yang ada pada diri anak. Kegiatan ekstrakurikuler dilakukan setiap hari dari hari senin sampai Jumat. Maka dari itu, peneliti mengambil lokasi penelitian PAUD Islam Terpadu Alhamdulilah Yogyakarta karena kegiatan ekstrakurikuler dilakukan setiap hari. Adapun fokus penelitian ini untuk mengetahui manajemen ekstrakurikuler pada peserta didik di PAUD Islam Terpadu Alhamdulillah Yogyakarta.

\section{LITERATUR REVIEW}

Sejauh ini telah ada sejumlah hasil penelitian berkaitan dengan manajemen eksrakurikuler terhadap peserta didik di lembaga PAUD. literatur review yang dilakukan untuk melihat penelitian yang telah dilakukan sehingga penelitian ini berangkat dan mengisi kekosongan atau menambah titik kosong yang masih belum

${ }^{173}$ Fari Ulfah, Manajemen PAUD Pengembangan Jejaring Kemitraan Belajar (Yogyakarta: Pustaka Belajar, 2015).,hlm. 26. 
dilakukan oleh penelitian yang lain. Adapun penelitian yang telah dilakukan sebagai berikut:

Pertama, penelitian yang dilakukan oleh Septria Nurhasanah dan Indra Yeni yang berjudul Gambaran Ekstrakurikuler di TK Telkom School, Padang. Penelitian yang digunakan menggunakan metode deskriptif dengan pendekatan kualitatif. Setidaknya hasil penelitian ini menemukan lima kegiatan ekstrakurikuler yang dilakukan di TK School Telkom Padang yaitu, hafidz, menari, renang, komputer, dan marching band ${ }^{174}$. Kedua, penelitian yang dilaksanakan oleh Eni Rakhmawati yang berjudul Manajemen Ekstrakurikuler Pendidikan Anak Usia Dini (PAUD) dalam meningkatkan multiple inteligence. Penelitian ini dilakukan menggunakan kualitatif deskriptif. Setidaknya, penelitian ini menemukan bahwa manfaat ekstrakurikuler sangat penting dengan perkembangan kecerdasan anak usia dini ${ }^{175}$. Ketiga, Nurhidayati ${ }^{176}$, dengan judul Manajemen Kegiatan Ekstrakurikuler Di TK Islam Plus Mutiara Banguntapan Yogyakarta. Penelitian ini menggunakan pendekatan deskriptif kualitatif dalam metode yang digunakan. Berdasarkan hasil penelitian bahwa kegiatan ekstrakurikuler dilaksanakan bervariasi. Setidaknya ada beberapa kegiatan ekstrakurikuler yang dilaksanakan di TK Islam Plus Mutiara yaitu: Drumband, Angklung, Menari, Menyanyi, Melukis, Renang, Sanggar AlQuran, Matematika Dahsyat, Multimedia, Baca Tulis dan Berhitung, Manasik Haji Kids, Pesantren Ramadan, Field Trip. Dan outbound family.

\section{METODE PENELITIAN}

Penelitian ini menggunakan penelitian kualitatif dengan pendekatan deskriptif. Hal ini dilakukan dengan masalah yang diteliti yaitu untuk mendeskripsikan tentang bagaimana manajemen ekstrakurikuler pada peserta didik di PAUD Islam Terpadu Alhamdulillah Yogyakarta. Adapun fokus penelitian ini untuk mengetahui manajemen ekstrakurikuler pada peserta didik di PAUD Islam Terpadu Alhamdulillah Yogyakarta.

\section{PEMBAHASAN DAN HASIL PENELITIAN}

\section{Tahapan Manajemen Ekstrakurikuler PAUD}

Sebagai lembaga yang memiliki peranyang sangat penting dalam masa GoldenAge, masa-masa yang sangat berharga bagianak yang merupakan pijakan kepadaperkembangan selanjutnya, diperlukanpenunjang yang dapat mendukungpengembangan dan pembinaan potensianak baik secara akademik

${ }^{174}$ Septria Nurhasanah \& Indra Yeni, Gambaran Ekstrakurikuler Di TK Telkom School Padang, dalam jurnal Islamic Early Childhood Education, Volume 4, Nomor 1, 2019.

${ }^{175}$ Eni Rakhmawati, Manajemen Ekstrakurikuler Pendidikan Anak Usia Dini (PAUD) Dalam Meningkatkan Multiple Inteligence, dalam jurnal La-Tahzan: Jurnal Pendidikan Islam, Volume 11, Nomor 2, 2019.

${ }^{176}$ Nurhidayati, Manajemen Kegiatan Ekstrakurikular di TK Islam Terpadu Plus Mutiara Banguntapan Yogyakarta, dalam jurnal Al-Athfal, Volume 1, Nomor 2, 2018. 
maupun nonakademik. Karena setiap anak itu unikmemiliki karakter dan kecenderunganmasing-masing. Tidak semua anakberprestasi dan menonjol dalam bidangakademik, sebagian anak memiliki bakatdibidang non akademik.Kegiatan non akademik di sekolahbiasa disebut dengan kegiatanekstrakurikuler atau kegiatan di luar materipelajaran wajib. Kegiatan ini ada padasetiap jenjang pendidikan dari TamanKanak-kanak hingga tingkat Universitas. Kegiatan ekstrakurikuler merupakankegiatan yang di lakukan diluar jampelajaran biasa, pada waktu libur, di dalammaupun di luar sekolah, secara rutin atauhanya pada waktu tertentu saja".Kegiatan ekstrakurikuler yang bisadikembangkan di sekolah sangat beragam,seperti ekstrakurikuler dibidang olahraga,seni, dan lain-lain. ${ }^{177}$

\section{Perencanaan Ekstrakurikuler}

Sebelum kegiatan ekstrakulikuler berlangsung, hendaknya guru pembina kegiatan ekstrakulikuler menyusun rencana kegiatan ekstrakulikuler yang akan dilaksanakan. Penyusunan rancangan aktivitas ini dimaksudnya agar guru mempunyai suatu pedoman yang jelas dalam memimpin kegiatan ekstrakulikuler. Perencanaan ini sangat mempermudah guru dalam pelaksanaannya, selain itu juga memudahkan kepala sekolah dalam mengadakan supervisi. ${ }^{178}$

Perencanaan kegiatan ekstrakulikuler mencangkup beberapa komponen yang perlu menjadi pertimbangan:

a) Bidang atau materi kegiatan

Materi kegiatan adalah bidang-bidang pembinaan yang dapat ditetapkan oleh sekolah.

b) Jenis kegiatan

Jenis kegiatan yang dipilh sekolah untuk program ekstrakulikuler hendaknya yang mendukung perkembangan fisik motorik, dan seni pada anak. Jenis kegiatan yang mendukung perkembangan tersebut antara lain, drum band, menari, melukis, menggambar.

c) Tujuan dan hasil

Tujuan dari kegiatan ekstrakulikuler ini ditentukan untuk mengembangkan bakat yang dimiliki anak seperti perkembangan motorik kasar anak melalui (gerak, tangan, kaki, bahu, kepala), sebagai pengalaman kedepannya, meningkatkan kemandirian, melatih kerjasama dan meningkatkan kecerdasan musikal melalui irama yang didengar dan dimainkan.

${ }^{177}$ Winda Trimelia Utami, Indra Yeni, dan Yeswinda, "Pelaksanaan Kegiatan Ekstrakurikuler Tari Tradisional di Taman Kanak-Kanak Sani Ashila Padang," Jurnal Ilmiah Potensia. Vol. 4 (2) (2019). hlm.5794. Lihat juga. Rasyono, Ekstrakurikular Sebagai Dasar Pembinaan Olahraga Pelajar, dalam jurnal of Physical Education, Health and Sport, Volume 3, Nomor 1, 2016.,hlm.46.

\footnotetext{
${ }^{178}$ Suryosubroto, Proses Belajar Mengajar di Kelas (Jakarta: Rineka Cipta, 2002)., hlm.304.
} 
d) Saranan penunjang

Sarana penunjang diperlukan untuk mendukung kegiatan ekstrakulikuler. Dana untuk sarana penunjang bersumber dari dana sekolah dan iuran dari anggota.

e) Kendala atau hambatan

Kendala yang sering muncul yaitu kendala eksternal seperti cuaca yang tidak mendukung untuk melaksanakan kegiatan ekstrakulikuler di luar ruangan.

f) Waktu pelaksanaan

Waktu pelaksanaannya menyesuaikan jadwal yang terdapat pada sekolah masing-masing.

g) Penanggung jawab

Penanggung jawab keguatan ekstrakulikuler adalah kepala sekolah dan guru pembina ketika sedang melakukan pengawasan.

2. Pelaksanaan Ekstrakurikuler

Pelaksanaan kegiatan ekstrakulikuler berbeda-beda disetiap lembaga pendidikan. Namun, ada hal-hal yang harus dipertimbangkan dalam melaksanakan kegiatan ektrakulikuler yakni:

1) Kegiatan harus dapat mengembangkan 6 aspek perkembangan, yaitu aspek kognitif, nilai agama dan moral, seni dan kreativitas, bahasa, fisik motorik, dan sosial emosional.

2) Memberikan tempat untuk menyalurkan minat dan bakat, sehingga peserta didik terbiasa dengan kegiatan yang bermakna.

3) Adanya perencanaan dan persiapan serta pembinaan yang telah diperhitungkan sehingga kegiatan ekstrakulikuler mencapai tujuan.

4) Pelaksanaan kegiatan ekstrakulikuler dilakukan oleh seluruh peserta didik atau sebagian peserta didik.

Selain itu pembina juga memiliki tugas tambahan yang tidak kalah penting yaitu:

1) Mengadakan pra survei. Maksudnya adalah apabila suatu kegiatan dilaukan diluar sekolah, pembina melakukan survei di tempat tersebut. Untuk mengetahui tempat tersebut tepat atau tudak jika akan digunakan sebagai kegiatan ekstrakulikuler.

2) Mengadakan presentasi untuk setiap kali latihan.

3) Menerima uang khusus seperti tabungan, iuran, pembelian buku, dan sebagainya untuk keperluan penunjang kegiatan ekstrakulikuler.

4) Memberikan penilaian terhadap presentasi peserta didik setiap semester yang kemudian disampaikan dalam nilai raport. 
5) Tugas umum, yaitu mengatur ke tujuan apabila aktivitaas dilakukan diluar lingkungan sekolah, sepeti pertandingan, pertunjukkan, dan perjalanan.

Kegiatan ekstrakulikuler bertujuan untuk mengembangkan potensi yang dimiliki anak. Upaya ini akan optimal jika peserta didik sendiri secara aktif berupaya mengembangkan diri sendiri sesuai program-program yang disajikan oleh sekolah. Oleh karena itu sangat penting untuk menciptakan kondisi agar peserta didik dapat mengembang potensi secara optimal.

Kegiatan ekstrakulikuler sendiri mengacu pada beberapa hal yaitu:

1) Orientasi pada tujuan. Di sini sekolah dapat memilih ekstrakulikuler untung mengembangkan fisik motorik peserta didik atau yang lainnya.

2) Prinsip sosial dan keja sama, pada kegiatan ekstrakulikuler seperti pada kegiatan drum band dan menari yang mengajarkan anak untuk bekerja sama dengan temannya yang menjadi satu tim.

3) Prinsip motivasi. Guru pembina kegiatan ektstrakulikuler hendaknya memberikan motivasi kepada peserta didik seperti pesan-pesan yang membuat peserta didik semakin semangat dalam melakukan kegiatan ekstrakulikuler.

4) Prinsip pengkoordinasian dan tanggung jawab. Prinsip ini ditujukan kepada guru pembina kegiatan ektstrakulikuler.

5) Prinsip relevansi. Prinsip ini ada dua jenis yaitu prinsip relevansi internal dan eksternal. Secara internal, kegiatan ekstrakulikuler dapat membantu mengembangkan potensi yang dimiliki oleh anak. sedangkan secara eksternal, kegiatan ekstrakulikuler dapat menjadi sarana untuk mempromosikan lembaga kepada masyarakat. ${ }^{179}$

\section{Evaluasi Kegiatan Ekstrakurikuler}

Kegiatan evaluasi diadakan ketika kegiatan ekstrakulikuler telah selesai. Evaluasi sendiri bertujuan untuk mengetahui manfaat kegiatan ekstrakulikuler bagi peserta didik maupun bagi sekolah. Hasil evaluasi juga bermanfaat untuk mengetahui perkembangan, tujuan, dan hasil dari kegiatan ekstrakulikuler guna merencanakan peningkatan kegiatan yang akan datang.

\section{Faktor-faktor yang Mempengarui Kegiatan Ekstakulikuler PAUD}

Ada beberapa faktor yang mempengaruhi kegiatan ekstrakulikuler. Faktorfaktor yang mempengaruhi kegiatan ektrakulikuler adalah sebagai berikut:

${ }^{179}$ Hernawan A.H dkk., Pengembangan Kurikulum dan Pembelajaran (Jakarta: Universitas Terbuka, 2008). hlm.12-24. 


\section{Tersedianya Sarana Prsarana}

Sebagaimana kita ketahui bahwa sarana dan prasarana pendidikan adalah segala sarana fisik yang mendukung suatu kegiatan dalam proses pembelajaran. Sarana pendidikan terbagi menjadi alat pelajaran, alat peraga, dan media pembelajaran. Prasarana pendidikan meliputi bangunan sekolah dan perabotan sekolah. Kepala sekolah sebagai penanggung jawab dan pemimin sekolah hendaknya mengusahakan instrumen pendidikan yang dibutuhkan oleh sekolah. Salah satu bentuk yang dibutuhkan oleh sekolah yaitu adalah sarana dan prasarana. Apabila sarana dan prasarana yang kurang mendukung maka kegiatan ekstrakulikuler tidak berjalan dengan baik. Sarana dan prasarana adalah komponen penting yang dapat mempengaruhi proses pembelajaran di sebuah lembaga, oleh karena itu sarana dan prasarana kegiatan ekstrakulikuler perlu diperhitungkan.

\section{Tersedianya Dana}

Pembiayaan pendidikan adalah kemampuan internal sistem pendidikan untuk mengelola dana pendidikan secara efisien. Pembiayaan pendidikan tidak hanya menyangkut analisa sumber saja, tetapi jug menggunakan dana-dana secara efisien. Pembiayaan sangat menentukan kelangsungan kegiatan ekstrakulikuler. Alokasi dana harus disusun bedasarkan realita dan skala prioritas.

3. Penjadwalan

Penjadwalan merupakan salah satu kegiatan administrasi di sekolah. Jadwal ini dimaksudkan untuk mengatur program belajar, dan praktik. Kegiatan ekstrakulikuler biasanya dilakukan ketika peserta didik mendapatkan waktu luang, seperti setelah proses kegiatan belajar mengajar selesai atau pada hari libur.

Berdasarkan penjelasan tersebut maka dapat di ambil kesimpulan bahwa ada tiga faktor yang mempengaruhi kegiatan ekstrakulikuler, yaitu tersedianya sarana dan prasarana, dana, dan penjadwalan yang tepat. Apabila ketiga point ini dapat dilakukan dengan baik maka kegiatan ektstrakulikuler dapat berjalan sesuai dengan harapan. ${ }^{180}$

\section{Contoh Kegiatan Ekstrakulikuler pada PAUD}

Prinsip PAUD tercermin dalam kegiatan ekstrakurikuler anak usia dini. Hal ini diawali dari perencanaan, pengorganisasian, pelaksanaan dan evaluasi. Di samping itu, enam aspek perkembangan yang terdiri aspek nilai agama dan moral, fisik motorik, sosial emosional, kognitif, bahasa dan seni adalah hal pokok yang

${ }^{180}$ Erni Munastiwi, Manajemen Lembaga PAUD Untuk Pengelola Pemula (Yogyakarta: CV. Istana Agency, 2019).,hlm. 209-210. 
dievaluasi. Pertumbuhan dan perkembangan enam aspek merupakan hal penting dalam PAUD. Berbagai contoh kegiatan ekstrakurikuler yang ditetapkan berorientasi perkembangan anak dan kebutuhan anak. Kegiatan dikemas dalam permainan yang menarik minat dan bakat anak. Contoh jenis kegiatan ekstrakurikuler dan manfaatnya:

1. Tahsin dan Tahfidz. Kegiatan ini bermanfaat untuk mrnumbuhkan rasa cinta terhadap Al-Qur'an.

2. Seni Melukis/ Menggambar. Kegiatan ini bermanfaat untuk Mengembangkan kecerdasan visual dan imajinasi.

3. Seni Tari/ Gerak dan Lagu. Kegiatan ini bermanfaat untuk Mengembangkan kecerdasan kinestetik, melatih kedisilpinan, kekompakan dan mengenalkan budaya.

4. Aquatic/ Renang kegiatan ini bermanfaat untuk Melatih gerak reflek, pernafasan, ketangkasan, konsentrasi dan sosialisasi.

5. Drumb band anak. kegiatan ini bermanfaat untuk Mengembangkan karakter, sosialisasi, melatih focus dan disiplin, menstimulus perkembangan syaraf dan otak.

6. Outbond anak. kegiatan ini bermanfaat untuk Menumbuhkan rasa percaya diri, kerjasama, sosialisasi, menghilangkan kejenuhan, sarana hiburan, menumbuhkan cinta alam. ${ }^{181}$

\section{HASIL PENELITIAN}

\section{KONDISI OBJEKTIF PAUD ALHAMDULILLAH YOGYAKARTA}

Cukup gampang mencari lokasi PAUD Alhamdulillah. Lokasinya sangat cocok dengan karakter lembaga PAUD dalam mendidik anak usia dini. PAUD Alhamdulillah jauh dari lokasi pasar dan berada dipemukiman pedesaan, sehingga jauh dari bunyi hiruk pikuk perkotaan. Untuk alamat lengkapnya di jalan Kelurahan Kasihan RT 07/18 Tamantirto Kasihan Bantul, Yogyakarta. PAUD Alhamdulillah dari sejarahnya dibangun pada tahun 2002 untuk izin TK sedangkan untuk izin KB pada tahun 2015. Saat ini PAUD Alhamdulillah di kepalai oleh Dra. Inayah Al Wahfiyah dan dibantu oleh guru TK sebanyak 14 orang dan 5 orang guru play grup. Selain itu, PAUD Alhamdulillah juga mempunyai guru extra sebanyak 7 orang.

Untuk sarana pendidikan yang ada di PAUD Alhamdulillah dapat dikategorikan baik. Hal ini dapat dibuktikan akreditasi A yang dimiliki oleh PAUD Alhamdulillah. Diceritakan pada penulis oleh ibu Nur Izzah salah satu tenaga didik di PAUD Alhamdulillah, bahwa lokasi PAUD Alhamdulillah yang berada di kelurahan Kasihan. Untuk sarana penunjang kegiatan PAUD sebanyak 13 ruangan untuk TK dan 2 ruangan kelompok bermain. Dari segi kualitas tenaga didik PAUD

${ }^{181}$ Erni Munastiwi, Manajemen Ekstrakurikuler Pendidikan Anak Usia Dini (PAUD), Jurnal Manajemen Pendidikan Islam Volume, 2 Nomor, 3 November, 2018. 
Alhamdulillah sangat sudah berkompeten dalam memberikan pendidikan anak usia dini. Hal ini dapat dilihat dari kualifikasi lulusan yang dimiliki oleh tenaga didik PAUD Alhamdulillah sebanyak 14 orang tenaga didik seluruhnya mempunyai lulusan minimal strata 1 . Melihat dari lulusan yang dimiliki oleh tenaga didik di lembaga PAUD Alhamdulillah terlihat wajar dikarenakan kualitas dalam melakukan pendidikan kepada anak didik sangat sesuai dengan kualifikasi lulusan pendidikan terlebih corak PAUD Alhamdulillah sangat bernuansa Islam. Nuansa Islam dapat dilihat dari nama PAUD dan arsitektur bangunan PAUD Alhamdulillah. Ruangruang didesain sedemikian rupa, sehingga anak merasa senang berada didalamnya. Untuk menarik perhatian, pada ruangan kelas dan teras dihiasi berbagai karya anak. Dinding ruang maupun halaman digambar dengan gambar yang menarik dan berwarna cerah. Seperti yang penulis amati di PAUD Alhamdulillah mempunyai beberapa sentra, diantaranya: sentra cooking, sentra eksplorasi, sentra persiapan, sentra budaya, sentra seni \& kreatifitas, sentra main peran, sentra musik \& gerak tubuh, sentra bahan alam, sentra balok, dan agama. selain itu, sarana dan prasarana untuk anak bermain dan belajar juga sangat mendukung.

Secara umum PAUD Alhamdulillah memiliki tujuan, yaitu: pertama, terwujudnya sikap dan perilaku yang patuh dalam melaksanakan ajaran agama Islam, toleran terhadap pelaksanaan ibadah agama lain, serta hidup rukun dengan pemeluk agama lain. Kedua, terwujudnya perilaku anak yang berakhlakul karimah, jujur, dapat dipercaya dalam perkataan, tindakan dan perbuatan. Ketiga, terwujudnya anak yang berprilaku tertib, disiplin, dan patuh pada berbagai ketentuan dan peraturan. Keempat, menjadikan anak yang mampu berpikir, berkomunikasi, bertindak produktif dan kreatif melalui bahasa, musik, karya dan gerakan-gerakan sederhana. Kelima, terwujudnya anak yang mempunyai sikap dan perilaku yang mandiri, tidak mudah tergantung pada orang lain dalam menghadapi masalah dan menyelesaikan tugas-tugas. Keenam, terciptanya suasana belajar yang kondusif bagi penyelenggaraan pendidikan, perawatan, pengasuhan dan perlindungan anak. Ketujuh, membangun kerjasama dengan orangtua, masyarakat, dan lingkup terkait dalam rangka pengelolaan PAUD yang profesional, akuntabel dan berdaya saing. Kedelapan, menjadi lembaga rujukan bagi lembaga PAUD sekitar.

Sedangkan untuk Visi dari PAUD Alhamdulillah adalah "Terwujudnya manusia yang memiliki aqidah yang lurus, jujur, disipin, kreatif, dan mandiri”. Sedangkan Misi Paud Alhamdulillah. Pertama, membiasakan sikap dan perilaku yang patuh dalam melaksanakan ajaran agama Islam, toleran terhadap pelaksanaan ibadah agama lain, serta hidup rukun dengan pemeluk lain. kedua, melatih perilaku yang didasarkan pada upaya menjadikan dirinya sebagai orang yang selalu dapat dipercaya dalam perkataan dan perbuatan. Ketiga, melatih tindakan yang menunjukkan perilaku tertib dan patuh pada berbagai ketentuan dan peraturan. 
Keempat, memupuk cara berpikir dan melakukan sesuatu untuk menghasilkan cara atau hasil baru dari apa yang telah dimiliki. Kelima, melatih sikap dan perilaku yang tidak mudah tergantung pada orang lain dalam menyelesaikan tugas-tugas. Adapun Motto PAUD Islam terpadu Alhamdulillah adalah “ Membimbing Anak di Jalan Allah Dengan Cinta dan Kasih Sayang”.

\section{MANAJEMEN EKSTRAKURIKULER DI PAUD IT ALHAMDULILLAH YOGYAKARTA}

Berdasarkan hasil wawancara dan observasi yang dilakukan di PAUD IT Alhamdulillah Yogyakarta bahwa manajemen ekstrakurikuler dilaksanakan pada mulai awal masuk sekolah. Kegiatan ekstrakurikuler dilakukan semenjak dari bulan Agustus 2001 dan sudah berlangsung 18 tahun. Adapun bentuk kegiatan ekstrakurikuler yang dilakukan oleh PAUD IT Alhamdulillah bertujuan agar bakat dan minat yang dimiliki oleh seorang anak dapat terwadahi. Hal ini relevan dengan pandangan Wiyani bahwa ekstrakurikuler pada hakikatnya kegiatan yang dilakukan bertujuan agar dapat mengembangkan aspek yang ada pada kurikulum. Selain itu, ekstrakurikuler dilakukan agar peserta didik mampu mengimplementasikan ilmu pengetahuan dan mampu beradaptasi dengan lingkungan sekitar. Ekstrakurikuler bertujuan mengembangkan bakat, minat, kepribadian, kemampuan, kerjasama, dan kemandirian untuk mencapai tujuan pendidikan nasional. ${ }^{182}$

Kegiatan ekstrakurikuler yang dilakukan oleh pihak PAUD IT Alhamdulillah merupakan kegiatan yang dilakukan setiap hari baik dari hari senin sampai kamis. Baik, dari jam 11.00-02.00 WIB. Sedangkan untuk pembiayaan dalam mengikuti ekstrakurikuler sudah termasuk pembiayaan awal sekolah sehingga orangtua dari peserta didik tidak perlu membayar iuran tambahan ketika anak mengikuti ekstrakurikuler. Setidaknya ada 3 kegiatan ekstrakurikuler yang dilaksanakan di PAUD IT Alhamdulillah Yogyakarta, yaitu:

\begin{tabular}{|l|l|l|l|}
\hline NO & Jenis Kegiatan Ekstrakurikuler & Hari & Jam \\
\hline 1. & Drumband & $\begin{array}{l}\text { Senin, Selasa, Rabu } \\
\text { dan Kamis }\end{array}$ & $\begin{array}{l}11.00 \text { WIB sampai } \\
14.00 \text { WIB }\end{array}$ \\
\hline 2. & Menari & Rabu & $\begin{array}{l}11.00 \text { WIB sampai } \\
14.00 \text { WIB }\end{array}$ \\
\hline 3. & Melukis & Selasa & 11.00 WIB sampai \\
& & & 14.00 WIB \\
\hline
\end{tabular}

\footnotetext{
${ }^{182}$ Noor, Yanti, dkk, Pelaksanaan Kegiatan Ekstrakurikuler Dalam Rangka Pengembangan NilaiNilai Karakter Siswa Untuk Menjadi Warga Negara Yang Baik Di SMA KORPRI Banjarmasin, dalam jurnal Pendidikan Kewarganegaraan, Volume 6, Nomor 11, 2016.,hlm.965.
} 
Sumber: Hasil wawancara dengan Ibu Dewi Rabu 4 Desember 2019

Kegiatan ekstrakurikuler yang dilaksanakan di PAUD IT Alhamdulillah Yogyakarta setelah kegiatan belajar mengajar. Untuk guru ekstrakurikuler yang ada di PAUD IT Alhamdulillah Yogyakarta berasal dari luar dan menggunakan guru yang telah professional dalam bidangnya. Untuk kegiatan Drumband peserta didik yang berada dibangku kelas B wajib mengikutinya. Sedangkan, kelas A tidak wajib mengikuti kegiatan Drumband. Selain itu, ada tambahan pembiayaan dalam pelaksanaan kegiatan Drumband. Untuk jumlah peserta didik tahun pelajaran 2019/2020 berjumlah 260 anak di KB. Kegiatan ekstrakurikuler dilakukan secara rutin setiap hari.

Pelaksanaan ekstrakurikuler yang dilakukan oleh pihak PAUD IT Alhamdulillah merupakan jenis kegiatan yang telah dikembangkan sesuai minat dan bakat anak. Kegiatan rutin ekstrakurikuler yang dilakukan setiap hari merupakan kegiatan terpisah dari kegiatan ekstrkurikuler yang lain, seperti: mengaji, outbound, berkunjung tempat wisata, dan lain-lain. Kegiatan ekstrakurikuler bukan hanya semata-mata kegiatan untuk menghabiskan waktu anak melainkan juga melakukan penanaman nilai keIslaman pada diri anak. Tidak hanya itu, kegiatan ekstrakurikuler yang dilaksanakan juga membangun karakter anak karena dalam kegiatan yang dilakukan pada saat ekstrakurikuler guru menumbuhkan nilai Islam dan nilai karakter dalam pelaksanaannya.

Manajemen ekstrakurikuler yang dilakukan oleh pihak PAUD IT Alhamdulillah Yogyakarta merupakan salah satu wujud dari program yang telah direncanakan.Adapun manajemen yang dilakukan berupa perencanaan, pengorganisasiaan, pelaksanaan, dam evaluasi. Perencanaan dilakukan oleh pihak PAUD IT Alhamdulillah pada saat penerimaan peserta didik. Pihak PAUD telah merancang sedemikian rupa termasuk dalam pembiayaan. Pengorganisasiaan dilakukan pada saat memilih guru ekstrakurikuler yang direkrut dari pihak luar yang mempuni dalam bidang ekstrakurikuler.

Pelaksanaan, juga mengikutsertakan guru yang ada di PAUD IT Alhamdulillah karena baik dari guru luar maupun guru tetap harus saling membantu dalam menumbuhkan aspek perkembangan anak. Terakhir, evaluasi yang dilakukan oleh pihak PAUD IT Alhamdulillah baik kepada peserta didik maupun kepada guru ekstrakurikuler. Evaluasi dilakukan untukk melihat sejauh mana perkembangan anak yang dilakukan oleh guru dalam membantu perkembangan anak. Tentu, evaluasi dilakukan supaya kegiatan ekstrakurikuler bermanfaat bagi perkembangana anak itu sendiri dan mampu meningkatkan minat dan bakat yang ada pada anak itu 
sendiri.Hal itu sejalan dengan pandangan Syamsul Kurniawan bahwa sekolah idealnya memunculkan pengetahuan dan pengalaman peserta didik. ${ }^{183}$

Pihak PAUD IT Alhamdulillah juga sering mengikutsertakan peserta didik dalam acara perlombaan seperti, Drumband, melukis, dan menari. Wujud dari mengikutsertakan peserta didik dalam mengikuti kegiatan perlombaan adalah sebagai evaluasi dan menumbuhkan sikap percaya diri peserta didik dan berani tampil ketika dilihat orang lain.

\section{SIMPULAN}

Berdasarkan hasil pembahasan dan deskripsi berkaitan manajemen ekstrakurikuler yang dilakukan di PAUD IT Alhamdulillah merupakan kegiatan yang dilakukan setelah kegiatan prosesb belajar mengajar. Kegiatan ekstrakurikuler dilaksanakan setiap hari belajar. Jumlah peserta didik yang mengikuti ekstrakurikuler berjumlah 260 orang sesuai dengan jumlah keseluruhan peserta didik. Manajemen ekstrakurikuler dilaksanaka juga dimulai dari tahap perencanaan, pemgorganisasiaan, pelaksanaan, dan evaluasi. Setidaknya ada 3 ekstrakurikuler yang rutin dilakukan setiap hari yaitu: Drumband, Melukis, dan Menari. Kegiatan ini dilakukan setiap hari belajar dan dilatih oleh guru yang mempuni dibidangnya. Guru ekstrakurikuler juga direkrut dari luar. Akan tetapi, ada kerjasama baik dari guru tetap dan guru luar dalam mengembangkan aspek perkembangan anak pada kegiatan ekstrakurikuler.

\section{DAFTAR PUSTAKA}

A.H, Hernawan, R Susilana, S Julaeha, dan W Sanjaya. Pengembangan Kurikulum dan Pembelajaran. Jakarta: Universitas Terbuka, 2008.

Kurniawan, Syamsul, Sekolah Progresif, dalam jurnal At-Turats, Volume 10, Nomor 1, 2016.

Munastiwi, Erni. 2018. "Manajemen Ekstrakurikuler Pendidikan Anak Usia Dini (PAUD)." Jurnal Manajemen Pendidikan Islam Volume,2 Nomor, 3,2018.

- - . Manajemen Lembaga PAUD Untuk Pengelola Pemula. Yogyakarta: CV. Istana

Agency, 2019.

${ }^{183}$ Syamsul Kurniawan, Sekolah Progresif, dalam jurnal At-Turats, Volume 10, Nomor 1, 2016.,hlm.10. 
Nurhasanah, Sepytia \& Yeni, Indra, Gambaran Ekstrakurikuler Di TK Telkom School Padang, dalam jurnal Islamic Early Childhood Education, Volume 4, Nomor 1, 2019.

Nurhidayati, Manajemen Kegiatan Ekstrakurikular di TK Islam Terpadu Plus Mutiara Banguntapan Yogyakarta, dalam jurnal Al-Athfal, Volume 1, Nomor 2, 2018.

Rakhmawati, Eni, Manajemen Ekstrakurikuler Pendidikan Anak Usia Dini (PAUD) Dalam Meningkatkan Multiple Inteligence, dalam jurnal La-Tahzan: Jurnal Pendidikan Islam, Volume 11, Nomor 2, 2019.

Rasyono, Ekstrakurikular Sebagai Dasar Pembinaan Olahraga Pelajar, dalam jurnal of Physical Education, Health and Sport, Volume 3, Nomor 1, 2016.

Suryosubroto. Proses Belajar Mengajar di Kelas. Jakarta: Rineka Cipta, 2002.

Ulfah, Fari. Manajemen PAUD Pengembangan Jejaring Kemitraan Belajar. Yogyakarta: Pustaka Belajar, 2015.

Utami, Winda Trimelia, Indra Yeni, dan Yeswinda. "Pelaksanaan Kegiatan Ekstrakurikuler Tari Tradisional di Taman Kanak-Kanak Sani Ashila Padang." Jurnal Ilmiah Potensia, Volume 4, Nomor 2, 2019.

Yanti, Noor, dkk, Pelaksanaan Kegiatan Ekstrakurikuler Dalam Rangka Pengembangan Nilai-Nilai Karakter Siswa Untuk Menjadi Warga Negara Yang Baik Di SMA KORPRI Banjarmasin, dalam jurnal Pendidikan Kewarganegaraan, Volume 6, Nomor 11, 2016. 